\title{
Comparison of the effectiveness of Aloe Vera Gel with $2 \%$ Nitrofurazone ointment on the healing of superficial second-degree burns. Randomised clinical trial
}

\section{Shokoh Varaei}

Tehran University of Medical Sciences School of Nursing and Midwifery hadi ranjbar

Iran University of Medical Sciences

parichehr sabaghzadeh ( $\square$ parichehr_sabaghzadeh@yahoo.com )

School of Nursing and Midwifery, Kerman University of Medical Sciences https://orcid.org/0000-00033760-5524 sanaz bostani

Hormozgan University of Medical Sciences School of Nursing and Midwifery

Soodabhe amirsalari

Tehran University of Medical Sciences

Research article

Keywords: Aloe Vera gel, 2\% Nitrofurazone, Burns, Dressing

Posted Date: July 28th, 2020

DOI: https://doi.org/10.21203/rs.3.rs-16854/v2

License: (c) (i) This work is licensed under a Creative Commons Attribution 4.0 International License. Read Full License

Version of Record: A version of this preprint was published at Nursing Practice Today on October 3rd, 2021. See the published version at https://doi.org/10.18502/npt.v9i1.7320. 


\section{Abstract}

Background: Burn injuries are one of the most common sources of trauma globally that comprise a significant drain on long-term personal and healthcare cost Large surface area burn wounds are difficult to manage and may result in significant physiologic and psychological sequelae. The aim of this study was to compare the effectiveness of Aloe Vera gel with $2 \%$ Nitrofurazone ointment in the healing of superficial partial thickness burns wounds.

Methods: The present study was a split body controlled, randomized clinical trial. The sample was recruited from patients with superficial partial thickness burns wound who were prescribed to treat with $2 \%$ Nitrofurazone ointment. Thirty patients with at least two burn, each burn on an alternate side of the body, entered the study - samples allocated to two area which received Aloe Vera gel or 2\% Nitrofurazone ointment on their burns. Bates-Jensen Wound. assessment tool (BWAT) was used to evaluate the healing of burns. the epithelialization parameter and sum score Bates-Jensen tools evaluated before, one, two and three weeks after the beginning of treatment.

Results: The mean \pm SD of epithelialization parameter in Aloe Vera area were $5.0 \pm 00.00,4.0 \pm 46.57$, $3.0 \pm 50.57,2.0 \pm 56.62$. The mean \pm SD of epithelialization parameter in $2 \%$ Nitrofurazone ointment area were $5.0 \pm 00.00,4.0 \pm 66.54,3.0 \pm 76.50,3.0 \pm 03.61$. and The mean \pm SD of BWAT scores in Aloe Vera area were $30.32 \pm 3.28,27.33 \pm 3.38,21.33 \pm 3.13,16.12 \pm 2.16$ respectively $(F(2,65.07)=440.00, p=0.001)$. The mean \pm SD of BWAT scores in $2 \%$ Nitrofurazone ointment area were $30.51 \pm 3.79,28.45 \pm 3.49,23.36$ $\pm 2.89,19.23 \pm 2.11(F(1,52.00)=228.00, p=0.001)$.

Conclusions: There is a significant difference in epithelialization parameter and (BWAT) scores between intervention and control area. Based on this study it looks like that aloe vera gel could promoted epithelialization and wound closure more effectively than $2 \%$ Nitrofurazone ointment

\section{Background}

Burn injuries are among the most common causes of hospitalization $(1,2)$. They are responsible for $5 \%$ of hospitalization worldwide and have a higher burden in developing countries(3) About $90 \%$ of burns occur in Low and middle-income countries, where health facilities are more limited (4). Patients with burn injuries are at risk of short and long term complications (5). Delay in burn wound healing is one of these complications (6). The healing of burn wounds is very critical in the process of recovery and rehabilitation of these patients (7).

Burns can occur when the skin is exposed to a high degree of heat from fire or hot liquids, electricity, chemicals, or radiation. Burns are classified according to the severity of tissue damage.

The American Burn Association ( $A B A$ ) has published an educational resource that reviewed the classification and management of the burn wound. The classification system below is largely in agreement. Superficial or epidermal burns involve only the epidermal layer of skin. They do not blister but 
are painful, dry, red, and blanch with. Partial-thickness burns involve the epidermis and portions of the dermis. They are characterized as either superficial or deep. Superficial partial thickness These burns characteristically form blisters within 24 hours between the epidermis and dermis. They are painful, red, and weeping and blanch with pressure. These burns generally heal in 7 to 21 days; scarring is unusual, although pigment changes may occur. A layer of fibrinous exudates and necrotic debris may accumulate on the surface, which may predispose the burn wound to heavy bacterial colonization and delayed healing. These burns typically heal without functional impairment or hypertrophic scarring. Deep partial thickness - These burns extend into the deeper dermis. Deep burns damage hair follicles and glandular tissue. They are painful to pressure only, almost always blister (easily unroofed), are wet or waxy dry. Fullthickness - These burns extend through and destroy all layers of the dermis and often injure the underlying subcutaneous tissue. Extension to deep tissues - Fourth-degree burns are deep and potentially life-threatening injuries that extend through the skin into underlying soft tissue and can involve muscle and/or bone (8).

Dressing burns with medicines that help wound healing can have an important role in reducing complications. All burns may cause complications if not properly treated (9)

One of the routine treatments of superficial partial thickness burns is daily washing and dressing with $2 \%$ Nitrofurazone ointment (10). $2 \%$ Nitrofurazone ointment is a topical anti-infective agent which is effective against gram-negative and gram-positive bacteria $(11,12)$. This ointment is widely used to treat various types of superficial wounds including burns. However, complications such as localized and limited drug absorption in the wound, drug resistance, allergic dermatitis, burning, edema, erythema, renal impairment, thrombocytopenia, itching, and blisters have been reported. Due to these complications, researches are conducting to find less complicated and effective alternatives for the treatment of burns (13-19). Aloe Vera is a clump-forming, perennial succulent with basal rosettes of tapering thick leaves. This plant has thick, juicy and coarse leaves. The middle of the leaves is filled with a high viscosity transparent gel (20, 21). Aloe Vera gel contains collagen, which can enhance the tissue granules and its anti-inflammatory properties can be effective in the process of wound healing and epithelialization (22-24)The antiinflammatory effect of Aloe Vera is due to the existence of salicylic acid and Arachidonic acid (25). Salicylic acid inhibits the production of Bradykinin and histamine. Arachidonic acid inhibits prostaglandin production $(26,27)$ Research has shown that Aloe Vera has

bacteriostatic and bactericidal effects on species such as Pseudomonas Aeruginosa, Escherichia coli, Salmonella Typhi and Mycobacterium tuberculosis (28). The results study showed that aloe vera be effective in shortening the duration of wound healing in superficial partial thickness burns(29-31), and it tended to increase rate of success to healing and rate of epithelialization (32).

Recovery of burns is a long and painful process that causes the suffering of the patient and the family and imposes substantial costs on them. superficial partial thickness burns generally heal in 7 to 21 days. Decreasing recovery time can reduce patient suffering and the cost of treatment (33). superficial partial thickness burns are the most painful types of burns. Treatment for this type of burn should be done with 
minimal skin irritation. As the Aloe Vera, in addition to its antimicrobial properties, has the effect of moisturizing and reducing irritation, it can be an excellent ingredient for superficial partial thickness burns dressing(34).

Therefor the purpose of this study was to compare the effect of Aloe vera gel and conventional treatment ( $2 \%$ Nitrofurazone ointment) on healing of superficial partial thickness burns.

\section{Methods}

\subsection{Study Design}

This study was a randomized split body controlled clinical trial. The study population consisted of all outpatients with superficial partial thickness burns who attended to Shafa hospital burn center, Kerman, Iran.

\subsection{Subjects and setting}

A convenience sample of 30 patients who had inclusion criteria enrolled in the study. Inclusion criteria were having superficial partial thickness burns with one burn positioned on the one side of the body and the other positioned on the alternate side of the body, total burns less than $20 \%$ of the body, each burn surface smaller than $16 \mathrm{~cm}$, no sign of infection and prescribing 2\% Nitrofurazone Ointment by Physician, no need for hospitalization, having physician permission to use Aloe Vera Gel instead of $2 \%$ Nitrofurazone Ointment, not being affiliated with underlying disease such as diabetes and immune deficiency such as cancer, AIDS and severe skin sensitivity and skin problems, the cause of the burn was contact with heat or hot liquids, admitting to the hospital before 6 hours, no material other than drinking water was used on the wound. in this study, one of the Inclusion criteria is the similarity in total BWAT score in both intervention and control areas. Statistical studies on all BWAT parameters, before the study, shown taht the homogeneity in these areas

Random allocation was done by the study statistician. researcher prepared 30 envelopes containing 15 cards labeled R and 15 cards labeled L. Each Patient selected an envelope. If the envelope with the letter $\mathrm{R}$ was opened, interventions would be done on the right side of the body, and vice versa. The other side of the body was treated with $2 \%$ Nitrofurazone ointment.

Wounds were washed daily with normal saline $0.9 \%$ and dressing with sterile gauze (Sterile gases had no secondary substances) In both intervention and control area a thin layer of gel and ointment was used to cover the whole wound, so about 15 to 20 grams was used based on the wound size. Dressings were changed on a daily basis (according to the routine of the hospital). The burned areas were evaluated for infection each day. Burn wound infection criteria were as detailed by the American Burn Association Consensus Conferences (including Change in color of the burnt area or surrounding skin, Purplish discoloration, mainly if swelling is also present, change in thickness of the burn (the burn suddenly extends deep into the skin), Greenish discharge or pus and Fever. Patients with signs of infection or 
Systemic Inflammatory Response Syndrome (SIRS) were excluded from the study. Sample recruitment and allocation are presented in figure 1 .

The primary outcome in this study achieve a replacement for $2 \%$ Nitrofurazone ointment in treatment of superficial partial thickness burns and promotion healing in superficial partial thickness burns.

The Bates-Jensen Wound Assessment Tool (BWAT) was used to evaluate wound healing (35). It is a validated wound assessment tool which is used in many healthcare settings for wound assessment. BWAT is straight forward to use and allows nurses to have an objective, comprehensive assessment of wounds. It consists of 13 items to evaluate wound size, type and depth, amount of necrotic tissue, amount and characteristics of exudate, the presence of granulation tissue, epithelialization, and peri-wound skin. The items and scoring are presented in table 1. Each item is graded on a scale of 1 to 5, where a score of 1 indicates progress toward healing while a score of 5 indicates the absence of healing or wound deterioration. Cumulative BWAT scores vary from 13 to 65 (36). Items and scoring of BWAT are presented in table 1. Two raters (First author and another nurse) scored all wounds simultaneously, the mean of two scores considered as BWAT score. The English version of BWAT has been reported to have good reliability (Cronbach alpha $=0.91$ and an interrater reliability coefficient of $0.99(37,38)$. Persian version of BWAT was used in previous studies (39), Twenty burns were assessed by two raters separately, and interrater reliability coefficient was 0.89 .

Table 1- Items and scoring of Bates-Jensen Wound Assessment Tool 


\begin{tabular}{|c|c|c|c|c|c|}
\hline Item & 1 & 2 & 3 & 4 & 5 \\
\hline $\begin{array}{l}\text { Size (Length * } \\
\text { width) }\end{array}$ & $<4 \mathrm{sq} \mathrm{cm}$ & $4--<16 \mathrm{sq} \mathrm{cm}$ & $16.1--<36 \mathrm{sq} \mathrm{cm}$ & $\begin{array}{l}36.1--<80 \mathrm{sq} \\
\mathrm{cm}\end{array}$ & $>80 \mathrm{sq} \mathrm{cm}$ \\
\hline Depth & $\begin{array}{l}\text { Non- } \\
\text { blanchable } \\
\text { erythema } \\
\text { on intact } \\
\text { skin }\end{array}$ & $\begin{array}{l}\text { Partial } \\
\text { thickness skin } \\
\text { loss involving } \\
\text { epidermis \&/or } \\
\text { dermis }\end{array}$ & $\begin{array}{l}\text { Full thickness skin loss involving damage } \\
\text { or necrosis of subcutaneous tissue; may } \\
\text { extend down to but not through underlying } \\
\text { fascia; \&/or mixed partial \& full thickness } \\
\text { \&/or tissue layers obscured by } \\
\text { granulation tissue }\end{array}$ & $\begin{array}{l}\text { Obscured by } \\
\text { necrosis }\end{array}$ & $\begin{array}{l}\text { Full thickness } \\
\text { skin loss with } \\
\text { extensive } \\
\text { destruction, } \\
\text { tissue } \\
\text { necrosis or } \\
\text { damage } \\
\text { muscle, bone } \\
\text { or supporting } \\
\text { structures }\end{array}$ \\
\hline Edges & $\begin{array}{l}\text { Indistinct, } \\
\text { diffuse, } \\
\text { none } \\
\text { clearly } \\
\text { visible }\end{array}$ & $\begin{array}{l}\text { Distinct, } \\
\text { outline clearly } \\
\text { visible, } \\
\text { attached, even } \\
\text { with wound } \\
\text { base }\end{array}$ & Well-defined, not attached to wound base & $\begin{array}{l}\text { Well- } \\
\text { defined, not } \\
\text { attached to } \\
\text { base, rolled } \\
\text { under, } \\
\text { thickened }\end{array}$ & $\begin{array}{l}\text { Well-defined, } \\
\text { fibrotic, } \\
\text { scarred or } \\
\text { hyperkeratotic }\end{array}$ \\
\hline Undermining & $\begin{array}{l}\text { None } \\
\text { present }\end{array}$ & $\begin{array}{l}\text { Undermining < } \\
2 \mathrm{~cm} \text { in any } \\
\text { area }\end{array}$ & $\begin{array}{l}\text { Undermining } 2-4 \mathrm{~cm} \text { involving }<50 \% \\
\text { wound margins }\end{array}$ & $\begin{array}{l}\text { Undermining } \\
2-4 \quad \mathrm{~cm} \\
\text { involving > } \\
50 \% \text { wound } \\
\text { margins }\end{array}$ & $\begin{array}{l}\text { Undermining } \\
>\quad 4 \mathrm{~cm} \text { or } \\
\text { Tunneling in } \\
\text { any area }\end{array}$ \\
\hline $\begin{array}{l}\text { Necrotic Tissue } \\
\text { Type }\end{array}$ & $\begin{array}{l}\text { None } \\
\text { visible }\end{array}$ & $\begin{array}{l}\text { White/grey } \\
\text { non-viable } \\
\text { tissue \&/or } \\
\text { non-adherent } \\
\text { yellow slough }\end{array}$ & Loosely a dherent yellow slough & $\begin{array}{l}\text { Adherent, } \\
\text { soft, black } \\
\text { eschar }\end{array}$ & $\begin{array}{l}\text { Firmly } \\
\text { adherent, } \\
\text { hard, black } \\
\text { eschar }\end{array}$ \\
\hline
\end{tabular}




\begin{tabular}{|c|c|c|c|c|c|}
\hline $\begin{array}{l}\text { Necrotic Tissue } \\
\text { Amount }\end{array}$ & $\begin{array}{l}\text { None } \\
\text { visible }\end{array}$ & $\begin{array}{l}<25 \% \text { of } \\
\text { wound bed } \\
\text { covered }\end{array}$ & $25 \%$ to $50 \%$ of wound covered & $\begin{array}{l}>50 \% \text { and < } \\
75 \% \text { of } \\
\text { wound } \\
\text { covered }\end{array}$ & $\begin{array}{l}75 \% \text { to } 100 \% \\
\text { of wound } \\
\text { covered }\end{array}$ \\
\hline Exudate Type & None & Bloody & $\begin{array}{l}\text { Serosanguineous: thin, watery, pale } \\
\mathrm{red} / \mathrm{pink}\end{array}$ & $\begin{array}{l}\text { Serous: thin, } \\
\text { watery, clear }\end{array}$ & $\begin{array}{l}\text { Purulent: thin } \\
\text { or thick, } \\
\text { opaque, } \\
\text { tan/yellow, } \\
\text { with or } \\
\text { without odor }\end{array}$ \\
\hline Exudate Amount & $\begin{array}{l}\text { None, dry } \\
\text { wound }\end{array}$ & $\begin{array}{l}\text { Scant, wound } \\
\text { moist but no } \\
\text { observable } \\
\text { exudate }\end{array}$ & Small & Moderate & Large \\
\hline $\begin{array}{l}\text { Skin Color } \\
\text { Surrounding } \\
\text { Wound }\end{array}$ & $\begin{array}{l}\text { Pink or } \\
\text { normal for } \\
\text { ethnic } \\
\text { area }\end{array}$ & $\begin{array}{l}\text { Bright red \&/or } \\
\text { blanches to } \\
\text { touch }\end{array}$ & White or grey pallor or hypopigmented & $\begin{array}{l}\text { Dark red or } \\
\text { purple \&/or } \\
\text { non- } \\
\text { blanchable }\end{array}$ & $\begin{array}{l}\text { Black or } \\
\text { hyper- } \\
\text { pigmented }\end{array}$ \\
\hline $\begin{array}{l}\text { Peripheral } \\
\text { Tissue Edema }\end{array}$ & $\begin{array}{l}\text { No } \\
\text { swelling or } \\
\text { edema }\end{array}$ & $\begin{array}{l}\text { Non-pitting } \\
\text { edema extends } \\
<4 \mathrm{~cm} \text { around } \\
\text { wound }\end{array}$ & $\begin{array}{l}\text { Non-pitting edema extends }>4 \mathrm{~cm} \text { around } \\
\text { wound }\end{array}$ & $\begin{array}{l}\text { Pitting } \\
\text { edema } \\
\text { extends }<4 \\
\text { cm around } \\
\text { wound }\end{array}$ & $\begin{array}{l}\text { Crepitus } \\
\text { and/or pitting } \\
\text { edema } \\
\text { extends }>4 \mathrm{~cm} \\
\text { around wound }\end{array}$ \\
\hline $\begin{array}{l}\text { Peripheral } \\
\text { Tissue } \\
\text { Induration }\end{array}$ & $\begin{array}{l}\text { None } \\
\text { present }\end{array}$ & $\begin{array}{l}\text { Induration, }<2 \\
\mathrm{~cm} \quad \text { around } \\
\text { wound }\end{array}$ & $\begin{array}{l}\text { Induration } 2-4 \mathrm{~cm} \text { extending }<50 \% \text { around } \\
\text { wound }\end{array}$ & $\begin{array}{l}\text { Induration 2- } \\
4 \quad \mathrm{~cm} \\
\text { extending > } \\
50 \% \text { around } \\
\text { wound }\end{array}$ & $\begin{array}{l}\text { Induration }>4 \\
\text { cm in any area } \\
\text { around wound }\end{array}$ \\
\hline $\begin{array}{l}\text { Granulation } \\
\text { Tissue }\end{array}$ & $\begin{array}{l}\text { Skin intact } \\
\text { or partial }\end{array}$ & $\begin{array}{l}\text { Bright, beefy } \\
\text { red; } 75 \% \text { to }\end{array}$ & $\begin{array}{l}\text { Bright, beefy red; }<75 \% \&>25 \% \text { of } \\
\text { wound filled }\end{array}$ & $\begin{array}{l}\text { Pink, \&/or } \\
\text { dull, dusky }\end{array}$ & $\begin{array}{l}\text { No } \\
\text { granulation }\end{array}$ \\
\hline
\end{tabular}




\begin{tabular}{|c|c|c|c|c|c|}
\hline & $\begin{array}{l}\text { thickness } \\
\text { wound }\end{array}$ & $\begin{array}{l}100 \% \text { of wound } \\
\text { filled \&/or } \\
\text { tissue } \\
\text { overgrowth }\end{array}$ & & $\begin{array}{l}\text { red \&/or fills } \\
<25 \% \text { of } \\
\text { wound }\end{array}$ & tissue present \\
\hline Epithelialization & $\begin{array}{l}100 \% \\
\text { wound } \\
\text { covered, } \\
\text { surface } \\
\text { intact }\end{array}$ & $\begin{array}{l}75 \% \text { to }<100 \% \\
\text { wound covered } \\
\text { \&/or epithelial } \\
\text { tissue extends } \\
>0.5 \mathrm{~cm} \text { into } \\
\text { wound bed }\end{array}$ & $\begin{array}{l}0 \% \text { to }<75 \% \text { wound covered \&/or } \\
\text { epithelial tissue extends to }<0.5 \mathrm{~cm} \text { into } \\
\text { wound bed }\end{array}$ & $\begin{array}{l}25 \% \text { to }< \\
50 \% \text { wound } \\
\text { covered }\end{array}$ & $\begin{array}{l}<25 \% \text { wound } \\
\text { covered }\end{array}$ \\
\hline
\end{tabular}

\subsection{Interventions}

Aloe Vera gel was extracted as $100 \%$ mucilage from the middle part of the Aloe Vera leaf, and sterilized by the Iranian Institute of Medical Plants. The intervention areas dressed with the Aloe Vera gel and the Control areas dressed with $2 \%$ Nitrofurazone Ointment. The first author who is a nurse with 5 years of work experience in burn center did all the dressings.

\subsection{Statistical Procedures}

The data was entered into SPSS Version 16. The BWAT scores and BWAT parameter reported as mean \pm SD. The Shapiro-Wilk test was used to test for normality $(p>0.05)$. The change in BWAT scores and BWAT parameter within each area was tested by repeated measure ANOVA. The paired sample t-test was used to compare the BWAT scores and BWAT parameter between two areas before, one, two and three weeks after intervention.

\section{Results}

The findings of this clinical study showed The mean and standard deviation of the age of the study units were $38.23 \pm 15.02$ years. (53.3\%) of the units were women. (56.7\%) participants were diploma and under diploma and (43.3\%) participants had a college 
degree. (53.3 \%) participants were single. The mean \pm SD of burn diameter in Aloe Vera gel and $2 \%$ Nitrofurazone areas were $26.2 \pm 0.63 \mathrm{~mm}$ and $25.8 \pm 0.62 \mathrm{~mm}$, respectively $(t=1.753, d f=28 \mathrm{p}=0.09, \mathrm{CI}:-0.12$ to 1.40$)$.

BWAT scores were not significantly different between the two areas before and one week after the intervention. The difference in BWAT scores between the two areas was significant in the second and third weeks. The BWAT scores within two areas' shows there is a statistical difference between wound closure in the two areas of control and intervention (Table 2 and figure 2).

In addition to comparing the sum scores derived from Bates-Jensen tools, individual parameters were also evaluated statistically in the two areas of 'control' and 'intervention'.

Comparative evaluation of Bates-Jensen epithelialization parameters in the second and third week revealed a significant statistical difference in the process of epithelialization in both aforementioned areas. (Table 3 and figure 3)

During the study, eight patients were excluded from the study. three of them did not come back for treatment and five patients had allergic reaction in the control area. Therefore, one of the medical staff who was blind to the objectives of the research was chosen to select eight other patients according to the entry criteria to be added to research

Table 2- The comparison of BWAT scores between and within two areas 


\begin{tabular}{|c|c|c|c|c|c|}
\hline $\begin{array}{l}\text { Time } \\
\text { Area }\end{array}$ & $\begin{array}{l}\text { Before } \\
\text { intervention }\end{array}$ & $\begin{array}{l}\text { First Week } \\
\text { after } \\
\text { intervention }\end{array}$ & $\begin{array}{l}\text { Second } \\
\text { Week after } \\
\text { intervention }\end{array}$ & $\begin{array}{l}\text { Third Week } \\
\text { after } \\
\text { intervention }\end{array}$ & $\begin{array}{l}\text { Repeated } \\
\text { Measure } \\
\text { ANOVA }\end{array}$ \\
\hline Aloe Vera & $30.32 \pm 3.28$ & $27.33 \pm 3.38$ & $21.33 \pm 3.13$ & $16.12 \pm 2.16$ & $\begin{array}{l}F(2, \\
65.07) \\
=440.00 \\
p=0.001\end{array}$ \\
\hline 2\%Nitrofurazone & $30.51 \pm 3.79$ & $28.45 \pm 3.49$ & $23.36 \pm 2.89$ & $19.23 \pm 2.11$ & $\begin{array}{l}F(1, \\
52.00) \\
=228.00, \\
p=0.001\end{array}$ \\
\hline t-test & $\begin{array}{l}t=-0.20, \\
d f=58, \\
p=0.41, C I= \\
-2.02 \quad \text { to } \\
1.64\end{array}$ & $\begin{array}{l}t=-1.26, \\
d f=58, \\
p=0.10, C I= \\
-2.89 \quad \text { to } \\
0.65\end{array}$ & $\begin{array}{l}t=-2.61, \\
d f=58, \\
p=0.006 \\
C I=-3.59 \text { to } \\
-0.46\end{array}$ & $\begin{array}{l}t=-5.64, \\
d f=58, \\
p=0.001, \\
C I=-4.21 \text { to } \\
-2.00\end{array}$ & \\
\hline
\end{tabular}

Table3: The Comparison of epithelialization parameter between two areas

\begin{tabular}{|l|c|l|l|c|}
\hline Time & $\begin{array}{l}\text { Before } \\
\text { intervention }\end{array}$ & $\begin{array}{l}\text { First Week after } \\
\text { intervention }\end{array}$ & $\begin{array}{l}\text { Second Week after } \\
\text { intervention }\end{array}$ & $\begin{array}{l}\text { Third Week after } \\
\text { intervention }\end{array}$ \\
\hline Aloe Vera & $5.0 \pm 00.00$ & $4.0 \pm 46.57$ & $3.0 \pm 50.57$ & $2.0 \pm 56.62$ \\
\hline 2\%Nitrofurazone & $5.0 \pm 00.00$ & $4.0 \pm 66.54$ & $3.0 \pm 76.50$ & $3.0 \pm 03.61$ \\
\hline $\begin{array}{l}\text { Repeated } \\
\text { Measure ANOVA }\end{array}$ & 1.00 & 0.234 & 0.037 & 0.003 \\
\hline
\end{tabular}

\section{Discussion}


According to this study, $2 \%$ Nitrofurazone and Aloe Vera gel both resulted in the healing of burn wounds. However, if the epithelialization parameter in Bates-Jensen tools in the two areas of control and intervention are compared, the progression of epithelialization in intervention area is better than the control area, in the second and third weeks. In spite of the fact that, both areas of control and intervention were studied on the same person and all environmental, physical and nutritional factors- influential in the healing process- were the same.

Also, comparing the sum score Bates-Jensen tools in both areas in second and third week, shows that the progression of wound closure in intervention area is better than the control area, in the second and third weeks. it looks like that aloe vera gel could promoted burn wound healing more effectively than $2 \%$ Nitrofurazone ointment

Alongside with a large number of studies stating that Aloe Vera improve(30, 40-43) and accelerates (4446) the healing process and epithelialization, a study, published in 2019 , states that nitrofuran drug class diminishes epithelialization of wounds(47).

Based on a detailed review of articles, the Aloe vera as a medicinal plant for skin wound healing is confirmed $(17,48)$. another method for skin wound healing is membranous dressings. While previous studies have shown that membranous dressings are more effective in partial thickness burns, they are also more expensive and needs extra education and equipment $(49,50)$.

Najafi et all reported the cause of the effectiveness of the Aloe Vera gel is that there are certain polysaccharides in it (14). These glycoproteins contain polysaccharides that stimulate the recovery of the skin. Glycoprotein fraction is the major component of aloe vera to be involved in wound healing with cell proliferation and migration (51).

Also Many Study past shown that Aloe Vera has a compound called glucomannan $(52,53)$. Glucomannan affects fibroblasts growth factor receptors and stimulates the activity and proliferation of these cells. This increases the production and secretion of collagen (54). Collagen is the major protein in the extracellular matrix and provides strength and integrity to the dermis and other supporting tissues (5456). Aloe vera mucilage enhances the production amount of collagen in the wound, modifies its structure. Increasing cross-connections between collagen strands accelerates wound healing $(55,56)$.

A study by Shahzad et al. showed that Thermal burns patients dressed with Aloe Vera gel showed advantage compared to those dressed with SSD regarding early wound epithelialization, earlier pain relief and cost-effectiveness(57). Another article revealed that aloe vera could be a treatment of choice for burn injuries (58). Hajhashemi proved evidences that topical application of aloe vera would improve of the healing wounds in rats(59). A clinical trial investigation reported that aloe vera and Calendula ointment improve the speed of episiotomy wound healing; therefore it could be considered for quickening the episiotomy healing (60). 
In other hand Aloe Vera dressing is classified in the category of wet dressings due to the presence of hydrocolloids $(34,45)$. Several studies have shown that wet dressings provide an ideal environment in regards to moisture and temperature for wounds $(61,62)$. Moisture increases the production of collagen and accelerates the formation of blood vessels, epithelialization and the formation of granular tissue (63, 64). Wet dressings can double the speed of wound healing because the wet environment allows fibroblast cells to immigrate faster to the epidermis and accelerate the recovery process $(65,66)$.

As well as Aloe Vera has lysine; lysine helps with wound healing by removing toxic substances, increasing blood flow and removing dead cells (67). The results of this study are consistent with the conclusion of a review study that showed that Aloe Vera gel promoted burns recovery(68) and promote Epithelialization Superficial or epidermal burns(69). Studies on wounds such as pressure ulcers, diabetic wounds, cesarean section, and episiotomy showed that the Aloe Vera gel was effective in wound healing and Epithelialization (17, 44, 60, 70-72). Comparison of the effect of Aloe Vera gel and $1 \%$ silver sulfadiazine cream on the recovery of superficial partial thickness burns in human and animale showed that the Aloe Vera Gel improves the wound more rapidly $(39,73)$. The results of another study showed that dressing with Aloe Vera gel was also effective in improving deep burn wounds $(68,74)$. In this study the outflow of samples were higher than what was expected this is one limitation in this study.

\section{Conclusion}

Based on this study it looks like that aloe vera gel could promoted epithelialization and wound closure more effectively than $2 \%$ Nitrofurazone ointment. therefor it can be said that patients visit the hospital less frequently for dressing changes, the risk of infection decreased hence, they can recover more quickly in their personal and social lives and decrease all cost treatment. And due to the systemic side effects of $2 \%$ Nitrofurazone ointment like renal impairment, thrombocytopenia, and allergic reactions, especially contact dermatitis and drug resistance, Aleo vera gel can be a good herbal alternative for $2 \%$ Nitrofurazone in superficial partial thickness burns. As researchers suggest, lack of comparative studies between Aleo vera and $2 \%$ Nitrofurazone, necessitates further studies with a larger number of samples.

\section{Abbreviations}

BWAT: The Bates-Jensen Wound Assessment Tool

\section{Declarations}

\section{Ethics approval and consent to participate:}

The study protocol was approved by the Ethics Committees of the Tehran University of Medical sciences (TUMS). The trial is registered in the Iranian Registry of Clinical Trials (IRCT2014113020151N1). Before participation in the study, written informed consent was obtained from each participant. All of them 
could withdraw from the study whenever they desired. The information on all research units was confidential.

\section{Consent to publish}

Not Applicable

\section{Availability of data and materials}

All data will be available on request. Everyone can request the data. To gain access, data requestors will need to sign a data access agreement. The data is available for any purpose. All applications should be sent to Parichehr_sabaghzadeh@yahoo.com. All requests will be answered within a maximum of 1 month by email.

\section{Competing interests:}

The authors declare that they have no competing interests

\section{Funding}

This study was funded and supported by Nursing and Midwifery Care Research Center, Tehran University of Medical sciences (TUMS); Grant no.27761

\section{Competing interests}

The authors declare that there is no conflict of interests.

\section{Authors' Contributions}

Investigation: SV, HR, PS, SB, SA

Methodology: SV, PS

Software: SV, HR

\section{Supervision: SV}

Writing - original draft: SV, HR, PS, SB, SA

Writing - review \& editing: SV, HR, PS, SB, SA

\section{Acknowledgement}

The authors would like to thank patients who participate in the study

\section{References}


1. Lotfi M, Ghahremaneian A, Aghazadeh A, Jamshidi F. The effect of pre-discharge training on the quality of life of burn patients. Journal of caring sciences. 2018;7(2):107.

2. Mirza Aghazadeh A, Lotfi M, Ghahramanian A, Ahadi F. Lethal area 50 in patients with burn injuries in North West, Iran. Journal of caring sciences. 2018;7(1):53-8.

3. Hosseini R, Askarian M, Assadian O. Epidemiology of hospitalized female burns patients in a burn centre in Shiraz. EMHJ-Eastern Mediterranean Health Journal, 13 (1), 113-118, 2007. 2007.

4. Peck MD. Epidemiology of burns throughout the World. Part II: intentional burns in adults. Burns. 2012;38(5):630-7.

5. Pham CH, Gillenwater TJ, Nagengast E, McCullough MC, Peng DH, Garner WL. Combination therapy: Etanercept and intravenous immunoglobulin for the acute treatment of Stevens-Johnson syndrome/toxic epidermal necrolysis. Burns. 2019;45(7):1634-8.

6. Muller M, Hollyoak M, Moaveni Z, Brown TLH, Herndon D, Heggers J. Retardation of wound healing by silver sulfadiazine is reversed by Aloe vera and nystatin. Burns. 2003;29(8):834-6.

7. Bano I, Arshad M, Yasin T, Ghauri MA. Preparation, characterization and evaluation of glycerol plasticized chitosan/PVA blends for burn wounds. International journal of biological macromolecules. 2019;124:155-62.

8. Puentes Marrugo AD, Salgar Sarmiento DA. Disminución posoperatoria de hemoglobina en paciente quemado, dependiente de procedimiento quirúrgico, superficie y grado de quemadura. 2019.

9. Oryan A, Alemzadeh E, Mohammadi AA, Moshiri A. Healing potential of injectable Aloe vera hydrogel loaded by adipose-derived stem cell in skin tissue-engineering in a rat burn wound model. Cell and tissue research. 2019;377(2):215-27.

10. Salehi H, Momeni M, Ebrahimi M, Fatemi M, Rahbar H, Ranjpoor F, et al. Comparing the effect of colactive plus ag dressing versus nitrofurazone and vaseline gauze dressing in the treatment of second-degree burns. Annals of burns and fire disasters. 2018;31(3):204.

11. Barati F, Javanbakht J, Adib-Hashemi F, Hosseini E, Safaeie R, Rajabian M, et al. RETRACTED ARTICLE: Histopathological and clinical evaluation of Kombucha tea and Nitrofurazone on cutaneous full-thickness wounds healing in rats: an experimental study. Diagnostic Pathology. 2013;8(1):826.

12. Noronha C, Almeida A. Local burn treatment-topical antimicrobial agents. Annals of Burns and Fire Disasters. 2000;13(4):216-9.

13. DARVISHPOUR A, LOTFI M, SALEHI F, AGHAZADEH A, HASANI A, AALI N. COMPARING DRESSING WITH SILVER SULFADIAZINE AND NITROFURAZONE ON BURN WOUND INFECTION MONG THE PATIENTS ADMITTED TO THE PEDIATRIC BURN WARD IN TABRIZ, 2005. JOURNAL OF GUILAN UNIVERSITY OF MEDICAL SCIENCES. 2006;15(60):-

14. Webber CE, Glanges E, Crenshaw CA. Treatment of second degree burns: Nitrofurazone, povidonelodine, and silver sulfadiazine. Journal of the American College of Emergency Physicians. 1977;6(11):486-90. 
15. Monafo WW, West MA. Current treatment recommendations for topical burn therapy. Drugs. 1990;40(3):364-73.

16. McCauley RL, Robson MC, Heggers JP. Alternating therapy in major burns: silver sulfadiazine vs. silver sulfadiazine-nitrofurazone. The Journal of Burn Care \& Rehabilitation. 1984;5(5):384-7.

17. Avijgan M, Kamran A, Abedini A. Effectiveness of Aloe vera gel in chronic ulcers in comparison with conventional treatments. Iranian journal of medical sciences. 2016;41(3 Suppl):S30.

18. Nashwan A, Basem D. Pharmacology Handbook for Clinical Practice: First Edition2010. 424 p.

19. Bilgili SG, Ozaydin-Yavuz G, Yavuz IH, Bilgili MA, Karadag AS. Cutaneous reactions caused by nitrofurazone. Advances in Dermatology and Allergology/Post $邓$ py Dermatologii i Alergologii. 2019;36(4):398.

20. Nazir A, Ahsan $\mathrm{H}$. Health benefits of aloe vera: A wonder plant. International Journal of Chemical Studies. 2017;5(6):967-9.

21. Srikanth K, Kartikeyan S, Kalla AM. Storage studies of Aloe vera juice incorporated Peda. International Journal of Food and Fermentation Technology. 2017;7(2):231-9.

22. Hashemi SA, Madani SA, Abediankenari S. The review on properties of Aloe vera in healing of cutaneous wounds. BioMed research international. 2015;2015.

23. Oryan A, Mohammadalipour A, Moshiri A, Tabandeh MR. Topical application of Aloe vera accelerated wound healing, modeling, and remodeling: an experimental study. Annals of plastic surgery. 2016;77(1):37-46.

24. Radha MH, Laxmipriya NP. Evaluation of biological properties and clinical effectiveness of Aloe vera: A systematic review. Journal of traditional and complementary medicine. 2015;5(1):21-6.

25. Benson KF, Newman RA, Jensen GS. Antioxidant, anti-inflammatory, anti-apoptotic, and skin regenerative properties of an Aloe vera-based extract of Nerium oleander leaves (NAE-8®). Clinical, Cosmetic and Investigational Dermatology. 2015;8:239.

26. Dat AD, Poon F, Pham KB, Doust J. Aloe vera for treating acute and chronic wounds. Cochrane Database of Systematic Reviews. 2012(2).

27. Paul S, Dutta S, Chaudhuri TK, Bhattacharjee S. Anti-inflammatory and protective properties of Aloe vera leaf crude gel in carrageenan induced acute inflammatory rat models. Int J Pharm Pharm Sci. 2014;6(9):368-71.

28. Pandey R, Mishra A. Antibacterial activities of crude extract of Aloe barbadensis to clinically isolated bacterial pathogens. Applied biochemistry and biotechnology. 2010;160(5):1356-61.

29. Akhtar MA, Hatwar S. Efficacy of aloe vera extract cream in management of burn wound. Journal of Clinical Epidemiology. 1996;49:S24.

30. Rodriguez-Bigas M, Cruz NI, Suarez A. Comparative evaluation of aloe vera in the management of burn wounds in guinea pigs. Plastic and reconstructive surgery. 1988;81(3):386-9.

31. Somboonwong J, Thanamittramanee S, Jariyapongskul A, Patumraj S. Therapeutic effects of Aloe vera on cutaneous microcirculation and wound healing in second degree burn model in rats. Journal 
of the Medical Association of Thailand= Chotmaihet thangphaet. 2000;83(4):417-25.

32. Irani PS, Varaie S. Comparison of the effect of Aloe vera Gel and Nitrofurazone $2 \%$ on epithelialization and granulation tissue formation regarding superficial second-degree burns. Iranian journal of medical sciences. 2016;41(3 Suppl):S3.

33. Zadeh A, Mahzooni T, Emami SA, Akbari H, Fatemi MJ, Saberi M, et al. The effect of Coriander cream on healing of superficial second degree burn wound. Tehran University Medical Journal. 2015;73(9):646-52.

34. Poletti S, Lucke LD, Acunha R, Mattos M, Gaspi F. Electromagnetic stimulation combined with aloe vera increases collagen reorganization in burn repair. Journal of Pharmacy and Pharmacology. 2018;6(7):633-46.

35. Sarpooshi HR, Mortazavi F, Vaheb M, Tabarayee Y. The Effects of Topical Vitamin C Solution on Burn Wounds Granulation: A Randomized Clinical Trial. J Biomed In Press (In Press) E. 2016;8301:1-5.

36. Harris C, Bates-Jensen B, Parslow N, Raizman R, Singh M, Ketchen R. Bates-Jensen wound assessment tool: pictorial guide validation project. Journal of Wound Ostomy \& Continence Nursing. 2010;37(3):253-9.

37. Alves DFdS, Almeida AOd, Silva JLG, Morais FI, Dantas SRPE, Alexandre NMC. Translation and adaptation of the Bates-Jensen wound assessment tool for the Brazilian culture. Texto \& ContextoEnfermagem. 2015;24(3):826-33.

38. Denby A, Rowlands A. Stop them at the door: should a pressure ulcer prevention protocol be implemented in the emergency department? Journal of Wound Ostomy \& Continence Nursing. 2010;37(1):35-8.

39. Ghaffarzadegan R, Alizadeh SA, Ghaffarzadegan R, Haji Agaei R, Ahmadlou M. Effect of aloe vera gel, compared to $1 \%$ silver sulfadiazine cream on second-degree burn wound healing. Complementary Medicine Journal. 2013;3(1):418-28.

40. Thamlikitkul V, Bunyapraphatsara N, Riewpaiboon W, Theerapong S, Chantrakul C, Thanaveerasuwan T, et al. Clinical trial of aloe vera Linn. for treatment of minor burns. Siriraj Medical Journal. 2017;43(5):313-6.

41. Moghbel A, Ghalambor A, Allipanah S. Wound healing and toxicity evaluation of Aloe vera cream on outpatients with second degree burns. Iranian Journal of Pharmaceutical Sciences. 2007;3(3):15760.

42. Eshghi F, Hosseinimehr SJ, Rahmani N, Khademloo M, Norozi MS, Hojati O. Effects of Aloe vera cream on posthemorrhoidectomy pain and wound healing: results of a randomized, blind, placebocontrol study. The Journal of Alternative and Complementary Medicine. 2010;16(6):647-50.

43. Thomas DR, Goode PS, LaMaster K, Tennyson T. Acemannan hydrogel dressing versus saline dressing for pressure ulcers. A randomized, controlled trial. Advances in wound care: the journal for prevention and healing. 1998;11(6):273-6.

44. Molazem Z, Mohseni F, Younesi M, Keshavarzi S. Aloe vera gel and cesarean wound healing; a randomized controlled clinical trial. Global journal of health science. 2015;7(1):203. 
45. Khorasani G, Ahmadi A, Jalal Hosseinimehr S, Ahmadi A, Taheri A, Fathi H. The effects of Aloe Vera cream on split-thickness skin graft donor site management: a randomized, blinded, placebocontrolled study. Wounds. 2011;23(2):44.

46. Burusapat C, Supawan M, Pruksapong C, Pitiseree A, Suwantemee C. Topical Aloe Vera Gel for Accelerated Wound Healing of Split-Thickness Skin Graft Donor Sites: A Double-Blind, Randomized, Controlled Trial and Systematic Review. Plastic and Reconstructive Surgery. 2018;142(1):217-26.

47. Altoé LS, Alves RS, Sarandy MM, Morais-Santos M, Novaes RD, Gonçalves RV. Does antibiotic use accelerate or retard cutaneous repair? A systematic review in animal models. PloS one. 2019;14(10):e0223511.

48. Dat AD, Poon F, Pham KB, Doust J. Aloe vera for treating acute and chronic wounds. The Cochrane database of systematic reviews. 2012(2):Cd008762.

49. Vloemans A, Soesman A, Suijker M, Kreis R, Middelkoop E. A randomised clinical trial comparing a hydrocolloid-derived dressing and glycerol preserved allograft skin in the management of partial thickness burns. Burns. 2003;29(7):702-10.

50. Ślęzak A, Kucharzewski M, Franek A, Twardokęs W. Evaluation of the efficiency of venous leg ulcer treatment with a membrane dressing. Medical engineering \& physics. 2004;26(1):53-60.

51. Choi SW, Son BW, Son YS, Park YI, Lee SK, Chung MH. The wound-healing effect of a glycoprotein fraction isolated from aloe vera. British Journal of Dermatology. 2001;145(4):535-45.

52. Gowda DC, Neelisiddaiah B, Anjaneyalu YV. Structural studies of polysaccharides from Aloe vera. Carbohydrate research. 1979;72:201-5.

53. Ni Y, Yates KM, Tizard IR. Aloe polysaccharides: CRC Press: Boca Raton; 2004.

54. Chithra P, Sajithlal GB, Chandrakasan G. Influence of Aloe vera on collagen characteristics in healing dermal wounds in rats. Mol Cell Biochem. 1998;181(1-2):71-6.

55. Chithra P, Sajithlal G, Chandrakasan G. Influence of Aloe vera on the glycosaminoglycans in the matrix of healing dermal wounds in rats. Journal of ethnopharmacology. 1998;59(3):179-86.

56. Chithra P, Sajithlal G, Chandrakasan G. Influence of Aloe vera on the healing of dermal wounds in diabetic rats. Journal of ethnopharmacology. 1998;59(3):195-201.

57. Shahzad MN, Ahmed N. Effectiveness of Aloe vera gel compared with $1 \%$ silver sulphadiazine cream as burn wound dressing in second degree burns. J Pak Med Assoc. 2013;63(2):225-30.

58. Feily A, Namazi MR. Aloe vera in dermatology: a brief review. G Ital Dermatol Venereol. 2009;144(1):85-91.

59. Hajhashemi V, Ghannadi A, Heidari AH. Anti-inflammatory and wound healing activities of Aloe littoralis in rats. Res Pharm Sci. 2012;7(2):73-8.

60. Eghdampour F, Jahdie F, Kheyrkhah M, Taghizadeh M, Naghizadeh S, Hagani H. The impact of Aloe vera and calendula on perineal healing after episiotomy in primiparous women: a randomized clinical trial. Journal of caring sciences. 2013;2(4):279. 
61. Li N. Meta analysis of the comparison of the effects between external application with Aloe vera and wet dressings with magnesium sulfate in the treatment of phlebitis. J Qilu Nurs. 2011;17:3-5.

62. Selamet F, Usman AM, Pamungkas RA. The Moisture Balance with Aloe Vera Gel in Diabetic Wound Healing. International Journal of Nursing and Health Services (IJNHS). 2018;1(1):21-3.

63. Carreira N, Loo R, Ranas S, Tupman R. Moist dressings and wound care. 2017.

64. Field CK, Kerstein MD. Overview of wound healing in a moist environment. The American journal of surgery. 1994;167(1):S2-S6.

65. Wiechula R. The use of moist wound-healing dressings in the management of split-thickness skin graft donor sites: a systematic review. International journal of nursing practice. 2003;9(2):S9-S17.

66. Seyedalshohadaee M, Rafii F, Hoseini A, Karimi H. Comparative study of the effect of dry and moist dressing on burn wound. Iran Journal of nursing. 2012;24(74):20-7.

67. Hamid AA, Soliman M. Effect of topical aloe vera on the process of healing of full-thickness skin burn: a histological and immunohistochemical study. Journal of Histology \& Histopathology. 2015;2(1):3.

68. Hekmatpou D, Mehrabi F, Rahzani K, Aminiyan A. The effect of aloe vera clinical trials on prevention and healing of skin wound: A systematic review. Iranian journal of medical sciences. 2019;44(1):1.

69. Kaufman T, Kalderon N, Ullmann Y, Berger J. Aloe Vera Gel Hindered Wound Healing of Experimental Second-Degree Burns: A Quantitative Controlled Study. The Journal of Burn Care \& Rehabilitation. 1988;9(2):156-9.

70. Hekmatpou D, Mehrabi F, Rahzani K, Aminiyan A. The effect of Aloe Vera gel on prevention of pressure ulcers in patients hospitalized in the orthopedic wards: a randomized triple-blind clinical trial. BMC complementary and alternative medicine. 2018;18(1):1-11.

71. Nazari S, Ezati Arasteh F, Nazari S, Shobeiri F, Shayan A, Parsa P. Effect of Aloe Vera gel on perineal pain and wound healing after episiotomy among primiparous women: A randomized clinical trial. The Iranian Journal of Obstetrics, Gynecology and Infertility. 2019;21(11):44-51.

72. Sabzaligol M, Safari N, Baghcjeghi N, Latifi M, Bekhradi R, Taghizadeh M, et al. The effect of Aloevera gel on prineal pain \& wound healing after episiotomy. Complementary Medicine Journal of faculty of Nursing \& Midwifery. 2014;4(2):766-75.

73. Akhoondinasab MR, Akhoondinasab M, Saberi M. Comparison of healing effect of aloe vera extract and silver sulfadiazine in burn injuries in experimental rat model. World J Plast Surg. 2014;3(1):2934.

74. Nasiri E, Hosseinimehr SJ, Azadbakht M, Madani SA. A review of natural products for burn healing based on the Iranian traditional medicine. Journal of Mazandaran University of Medical Sciences. 2014;23(110):263-80.

\section{Figures}




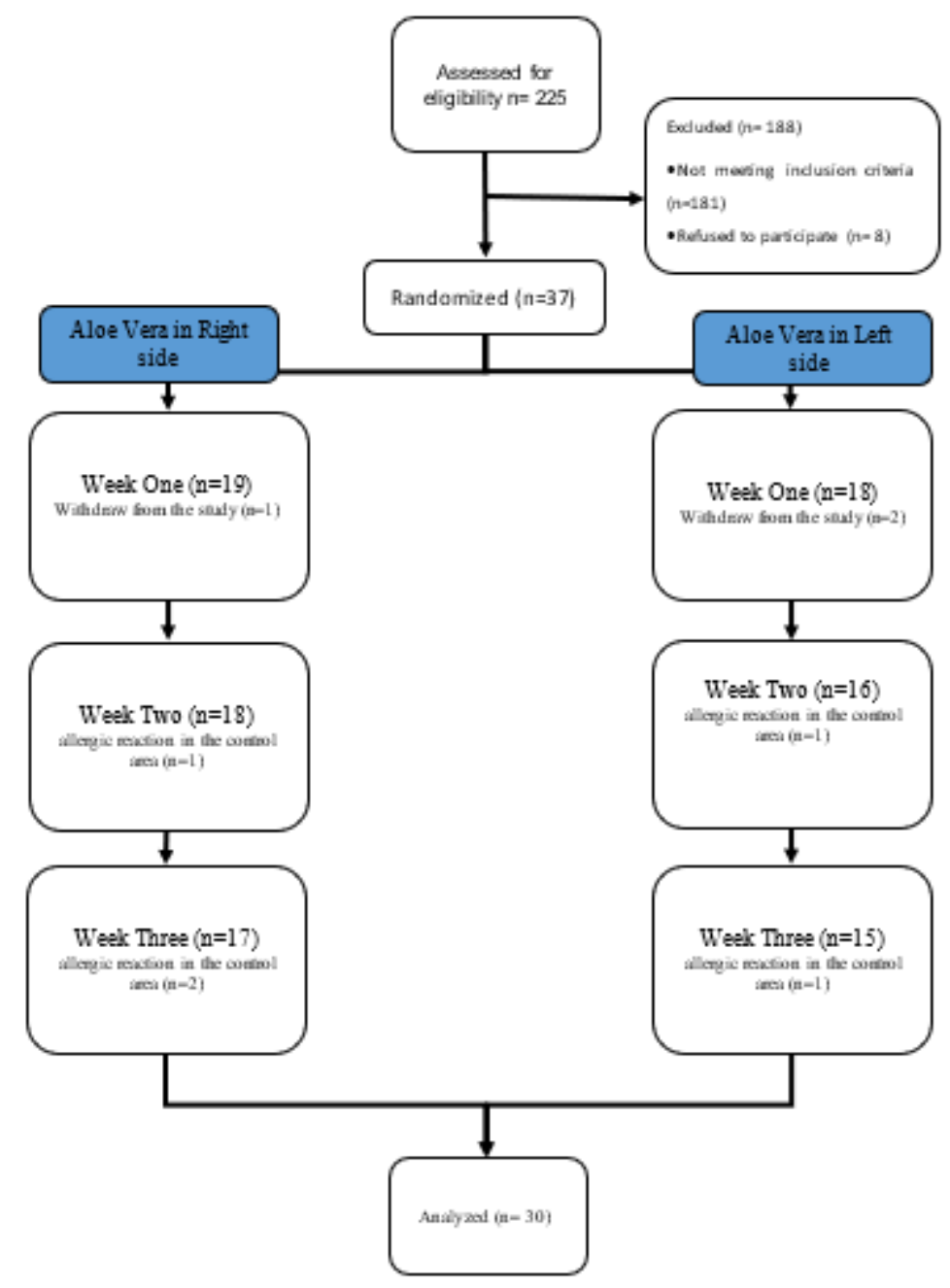

\section{Figure 1}

Study flowchart: recruitment and allocation to study areas

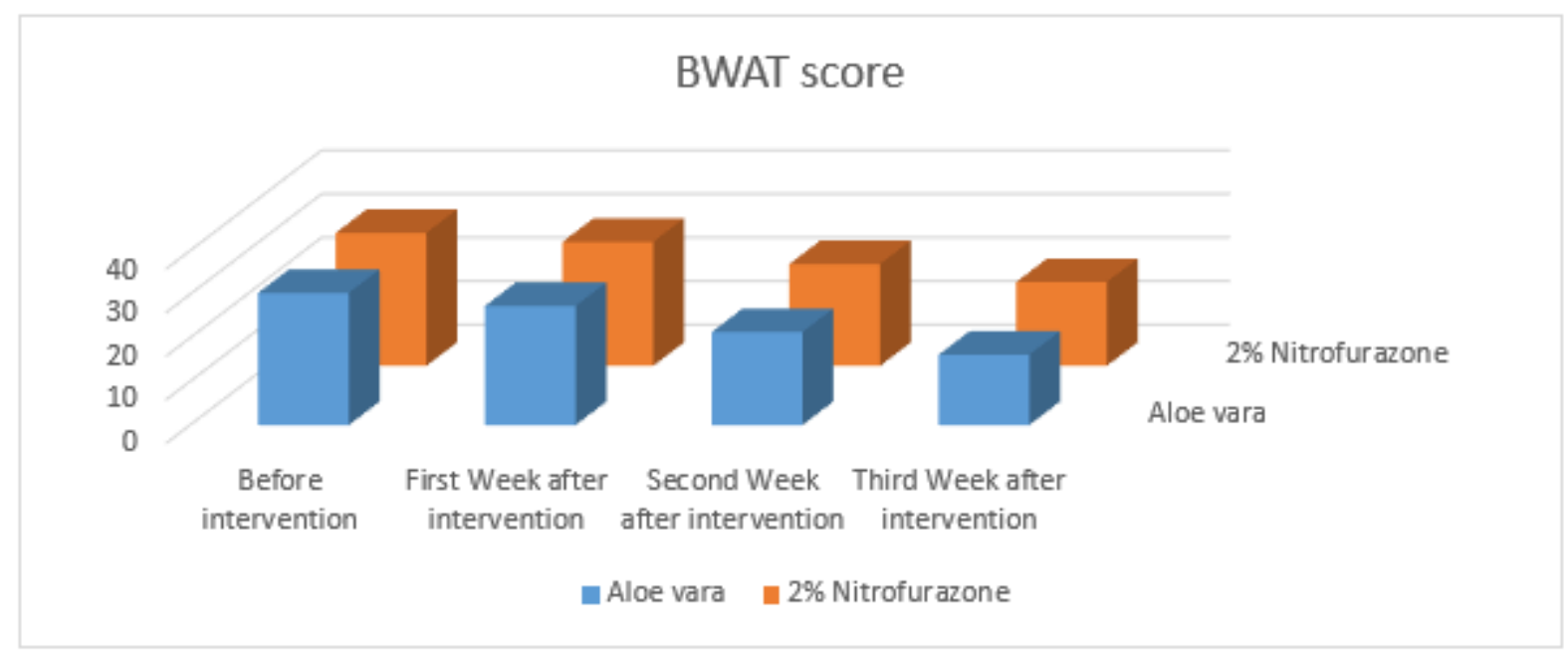

\section{Figure 2}

The comparison of BWAT scores between two areas 


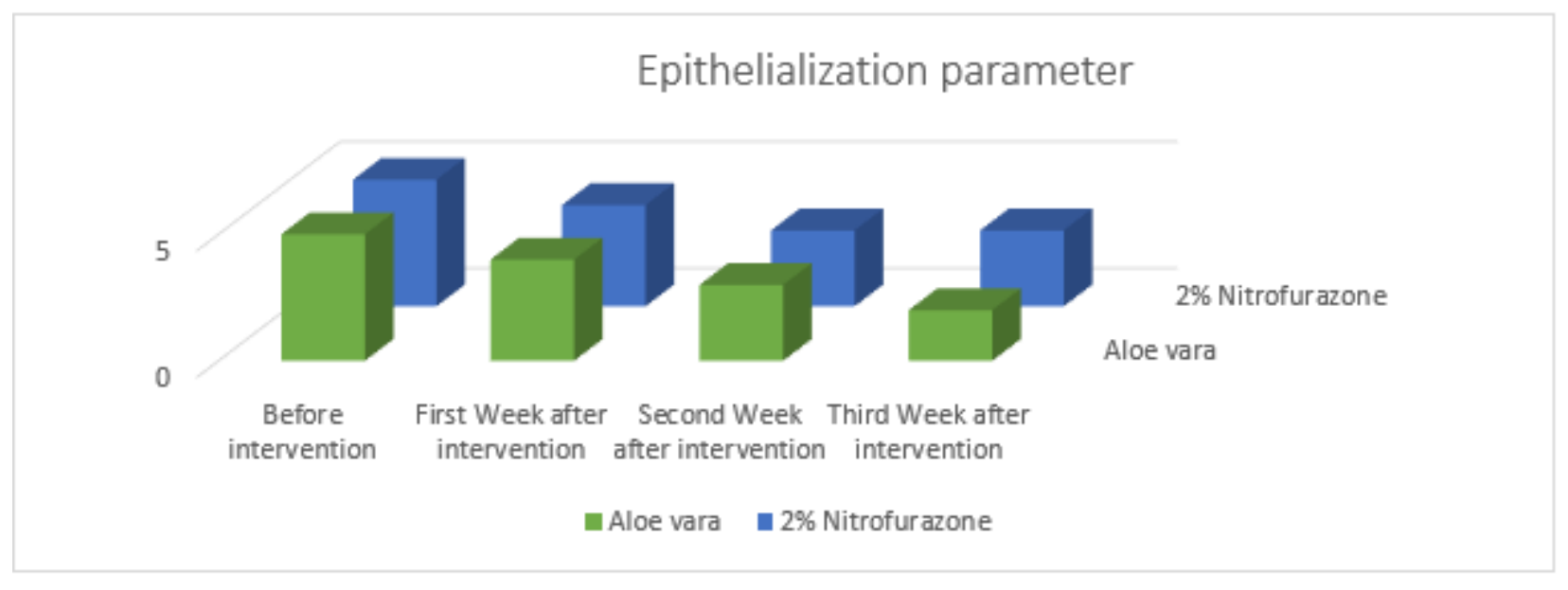

Figure 3

The Comparison of epithelialization parameter between two areas

\section{Supplementary Files}

This is a list of supplementary files associated with this preprint. Click to download.

- CONSORT2010Checklist1.doc 